\title{
Color Filter Identification for Bidirectional Visible Light Communication
}

\author{
ARSYAD RAMADHAN DARLIS, LITA LIDYAWATI, LUCIA JAMBOLA
}

\author{
Teknik Elektro Institut Teknologi Nasional Bandung \\ Email: arsyad@itenas.ac.id
}

Received 30 April 2018 | Revised 20 Mei 2018 | Accepted 30 Mei 2018

\begin{abstract}
ABSTRAK
Saat ini, cahaya tampak dimanfaatkan oleh manusia hanya sebagai penerangan saja. Akan tetapi, beberapa penelitian telah membuktikan bahwa cahaya tampak dapat dimanfaatkan pula pada sistem komunikasi, yang dinamakan Visible Light Communication (VLC). Pada penelitian ini, sebuah metoda menggunakan color filter diidentifikasi dalam mengimplementasikan sistem bidirectional pada teknologi VLC. Dengan adanya penelitian ini, sebuah sistem bidirectional Visible Light Communication (Bi-VLC) dapat diimplementasikan dengan menggunakan color filter tertentu yang dipasangkan pada posisi uplink dan downlink. Sinyal informasi berupa sinyal audio ditansmisikan melalui VLC transmitter (TX) yang dipasang color filter dan diterima oleh color filter pada VLC receiver (RX) setelah melalui media cahaya. Pengujian menunjukan bahwa sistem telah dapat melewatkan sinyal pada frekuensi audio dengan jarak maksimum dari sistem adalah 2,3 $\mathrm{m}$. Sedangkan pasangan color filter yang memiliki kinerja paling baik untuk BI-VLC adalah Azure (TX) dengan Charteuse Green (RX), Charteuse Green $(T X)$ dengan Charteuse Green $(R X)$, dan Rose $(T X)$ dengan Charteuse Green (RX).
\end{abstract}

Kata kunci: Bidirectional, Visible Light Communication (VLC), Color Filter, Audio

\begin{abstract}
Currently, visible light are utilized by humans as illumination only. However, several research have proven that visible light can also be used in communication systems, called Visible Light Communication (VLC). In this research, a method of using color filters was identified for bidirectional systems on VLC technology. With this research, a bidirectional Visible Light Communication (Bi-VLC) system can be implemented using a specific color filter paired in uplink and downlink mode. The audio signal as information is transmitted through a VLC transmitter $(T X)$ installed by a color filter and received by the color filter on the VLC receiver (Rx) after going through the light media. The result shows that the system has been able to pass the signal at the audio frequency with the maximum distance of the system is $2.3 \mathrm{~m}$. While the best performance of color filter pair for BI-VLC is Azure (TX) with Charteuse Green $(R x)$, Charteuse Green (TX) with Charteuse Green (RX), and Rose (TX) with Charteuse Green (RX).
\end{abstract}

Keywords: Bidirectional, Visible Light Communication (VLC), Color Filter, Audio 
Darlis, dkk

\section{PENDAHULUAN}

Cahaya tampak (Visible Light - VL) adalah radiasi elektromagnetik yang terlihat oleh mata manusia normal dengan panjang gelombang 380 sampai $750 \mathrm{~nm}$, sedangkan cahaya inframerah adalah radiasi elektromagnetik dengan panjang gelombang lebih panjang dari $\mathrm{VL}$, tetapi lebih pendek dari radiasi gelombang radio, dimana inframerah ini memiliki panjang gelombang antara $700 \mathrm{~nm}$ sampai dengan $1 \mathrm{~mm}$. Teknologi menggunakan inframerah sampai sekarang masih digunakan dalam sistem komunikasi. Teknologi ini digunakan pada berbagai peralatan, seperti remote televisi, air conditioner (AC), pointer untuk presentasi dan bahkan digunakan dalam sebuah sistem komunikasi, seperti halnya penelitian yang dilakukan oleh Jape Athan Bangun (Bangun, Lidyawati, \& Darlis, 2012) yang memanfaatkan fungsi cahaya dari infamerah sebagai media dalam sistem komunikasi. Pada penelitian ini didapatkan bahwa sinyal audio dapat dikirimkan dengan jarak 5 meter pada siang hari, dan 10.5 meter pada malam hari. Akan tetapi, teknologi ini memiliki keterbatasan dalam hal mobilitas.

Dibandingkan dengan teknologi tersebut, VL yang dihasilkan oleh lampu penerangan memiliki sifat yang sama dengan inframerah tersebut. Pada saat ini, VL dimanfaatkan oleh manusia untuk penerangan, baik indoor maupun outdoor. Hal ini disebabkan keduanya merupakan radiasi elektromagnetik, hanya saja memiliki panjang gelombang yang berbeda. Oleh karena itu, apabila inframerah dapat digunakan dalam sistem komunikasi, hal yang sama dapat dilakukan dengan menggunakan VL (Hanzo, Haas, Rupp, \& Gyongyosi). Pada beberapa penelitian telah dibuktikan bahwa VL dapat dimanfaatkan pula untuk kebutuhan lain, yaitu pada sistem komunikasi (Wu, Zhang, Dang, \& Liu, 2015) (Monteiro \& Hranilovic, 2014) (Liu et al., 2012). Sistem komunikasi dengan media cahaya memiliki potensi yang sangat besar dalam menggantikan media wireless. Hal ini disebabkan manusia tidak akan dapat bekerja dan hidup tanpa adanya lampu penerangan sehingga mobilitas dan tingkat efisiensinya sangat tinggi. Teknologi yang memanfaatkan visible light (VL) dalam sistem komunikasi dinamakan Visible Light Communication (VLC).

Teknologi ini sangat berguna mengingat bahwa pada tempat - tempat tertentu, komunikasi tidak dapat dilakukan dengan mudah menggunakan teknologi yang memanfaatkan gelombang elektromagnetik, misalnya di dalam air, terowongan atau di tempat yang tidak dapat menerima gelombang elektromagnetik (blank spot). Disamping itu, komunikasi antar manusia di tempat tersebut baik dalam bentuk audio, video, maupun data secara dua arah (bidirectional) menggunakan teknologi seluler tidak dapat dilakukan. Sistem komunikasi dalam mode bidirectional merupakan bentuk komunikasi antara 2 (dua) belah pihak yang saling mengirim dan menerima informasi dalam waktu bersamaan.

Penelitian mengenai VLC ini telah cukup berkembang, yaitu bermula dari penelitian pada tahun 2012, yang dilakukan oleh G. Cossu dan timnya (Cossu, Khalid, Choudhury, Corsini, \& Ciaramella, 2012) mencoba untuk mengirimkan sinyal dengan menggunakan LED tersebut. Penelitian ini dilakukan dengan cara mengirimkan data dengan menggunakan RGB LED dengan kecepatan 780 Mbit/s. Penelitian ini cukup berhasil sehingga data dapat diterima dengan baik pada jarak $2,5 \mathrm{~m}$. Penelitian ini lebih memperkuat asumsi bahwa cahaya yang dibangkitkan oleh LED dapat digunakan dalam mengirim data walaupun belum optimal.

Penelitian lain dilakukan oleh Khan dan timnya (Khan, Tahir, \& Usman, 2012) dimana mereka mengimplementasikan teknologi VLC untuk transmisi sinyal juga. Akan tetapi, sinyal yang dikirimkan memiliki jumlah yang banyak oleh karena itu digunakan metoda Wavelength Division Multiplexing (WDM). sinyal yang dikirimkan hanyalah sinyal biasa yang belum terlalu 
kompleks. Diketahui dari beberapa penelitian teknologi Visible Light Communication (VLC) harus memperhatikan penggunaan LED dan photodiode yang sesuai dengan sinyal informasinya (Khalid et al., 2012) (Liao, Chang, Ho, \& Wu, 2013) dan dapat menggunakan beberapa metoda dalam aplikasinya (Bykhovsky \& Arnon, 2014) (Chang et al., 2014) (Monteiro \& Hranilovic, 2014) (Singh, O'Farrell, \& David, 2014) (Wu et al., 2015). Serta dari beberapa penelitian lainnya didapatkan hasil yang mendukung pemanfaatan VLC sebagai teknologi masa depan yang patut diteliti lebih lanjut (Darlis, Cahyadi, \& Chung, 2018) (Hanzo et al., 2012) (Liu, Yeh, \& Chow, 2013).

Pada penelitian ini, sebuah metoda menggunakan filter warna (color filter) diidentifikasi dalam membuat sebuah sistem (bidirectional) pada teknologi Visible Light Communication (VLC). Dengan adanya penelitian ini, sebuah sistem bidirectional Visible Light Communication (Bi-VLC) dapat diimplementasikan dengan menggunakan color filter tertentu yang dipasangkan pada posisi uplink dan downlink. Beberapa color filter diujikan dalam beberapa skenario sehingga dihasilkan pasangan warna yang menghasilkan kinerja yang optimal dengan sinyal informasi berupa sinyal audio pada beberapa frekuensi.

\section{METODOLOGI}

Secara umum, sistem untuk membentuk Visible Light Communication (VLC) dibagi menjadi dua bagian, yaitu bagian Transmitter (Tx) dan Receiver (Rx). Sinyal informasi berupa sinyal audio yang dibangkitkan oleh signal generator dengan beberapa frekuensi dikirim melalui VLC transmitter dan ditransmisikan ke media udara menggunakan Light Emitting Diode (LED) yang telah dipasang filter warna (color filter) untuk membentuk sebuah panjang gelombang tertentu. Sinyal informasi tersebut diterima oleh color filter dengan panjang gelombang tertentu yang dipasang pada Photosensor dalam VLC Receiver, dan diukur kinerjanya menggunakan oscilloscope. Sistem VLC transmitter terdiri dari signal conditioner dan Light Emitting Diode (LED), sedangkan sistem VLC Receiver terdiri dari Photosensor berupa photodiode, Amplifier dan Signal Conditioner. Gambar 1 menunjukan blok diagram sistem Bidirectional Visible Light Communication (Bi-VLC) menggunakan color filter. Sedangkan Ilustrasi mengenai sistem yang akan diimplementasikan terlihat pada Gambar 2.

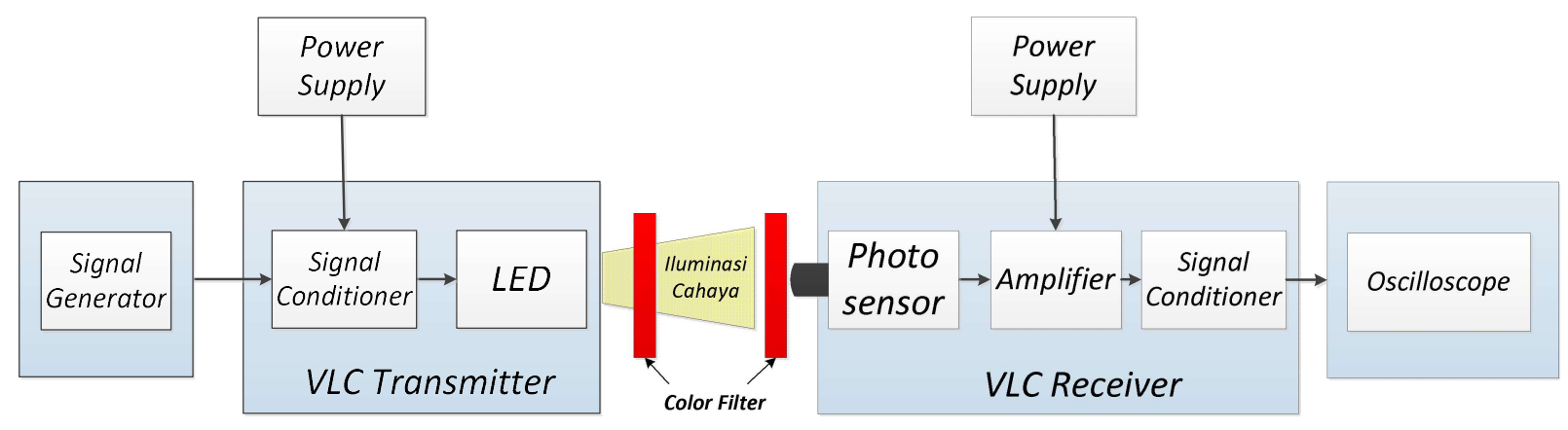

\section{Gambar 1. Blok Diagram sistem Bidirecional Visible Light Communication (Bi-VLC)} menggunakan Color Filter 


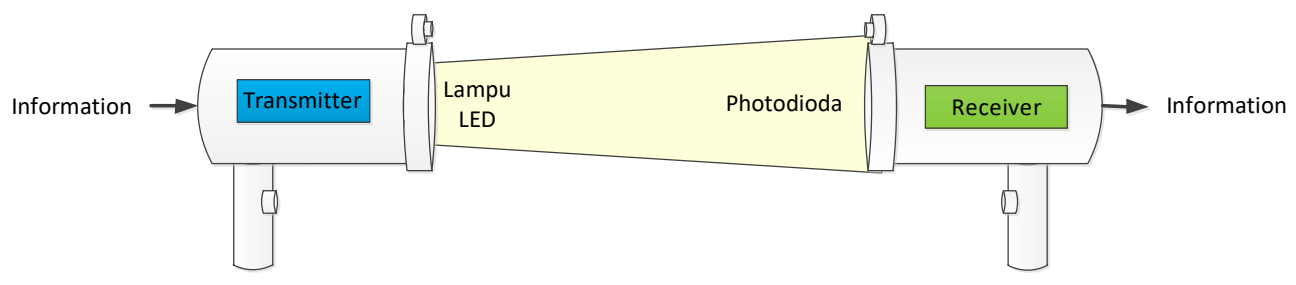

Gambar 2. Ilustrasi produk sistem Bidirecional Visible Light Communication (Bi-VLC) menggunakan Color Filter

\subsection{Perancangan Sistem}

Perancangan dilakukan dengan menggunakan simulasi terhadap rangkaian sistem yang diimplementasikan. Hal ini bertujuan untuk mengetahui kinerja dari sistem yang dibuat sebelum diimplementasikan. Simulasi dilakukan menggunakan perangkat lunak simulasi Electronic Workbench. Frekuensi yang terdapat pada audio adalah $300 \mathrm{~Hz}$ sampai dengan $3400 \mathrm{~Hz}$. Gambar 3 menunjukan hasil simulasi dari sistem yang telah disimulasikan dimana sinyal dengan frekuensi $2 \mathrm{kHz}$ dan tegangan 5 Volt sebagai sinyal informasi dikirimkan ke dalam sistem.

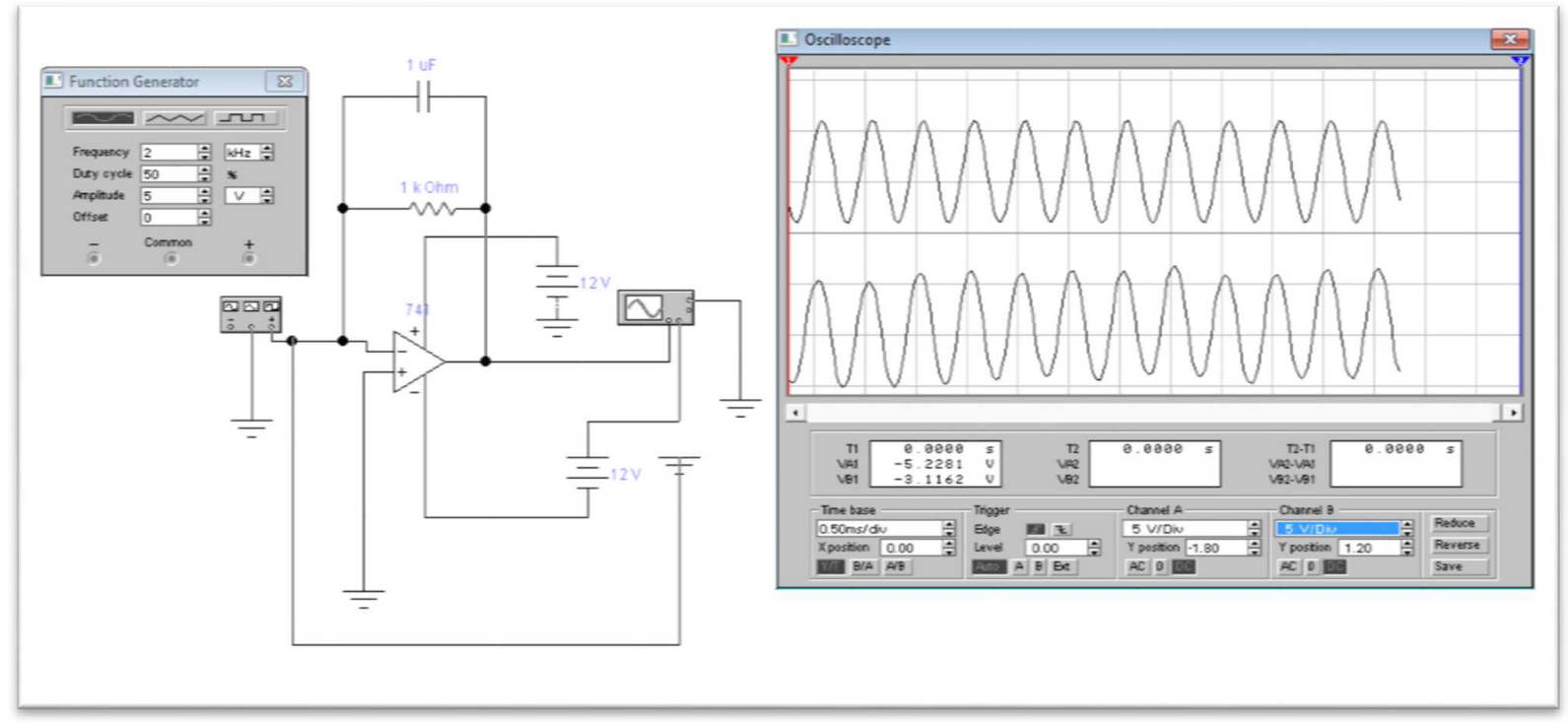

Gambar 3. Simulasi rangkaian VLC Transmitter yang dirancang

Pada Gambar 3 terlihat bahwa sinyal informas (ditunjukan pada gambar sinyal pada oscilloscope bagian atas) yang dikirimkan berupa sinyal sinusoida dengan frekuensi $2 \mathrm{kHz}$ dimasukkan ke dalam rangkaian yang telah dirancang, sehingga menghasilkan output (ditunjukan pada gambar sinyal pada oscilloscope bagian bawah) yang sesuai dengan inputnya. 


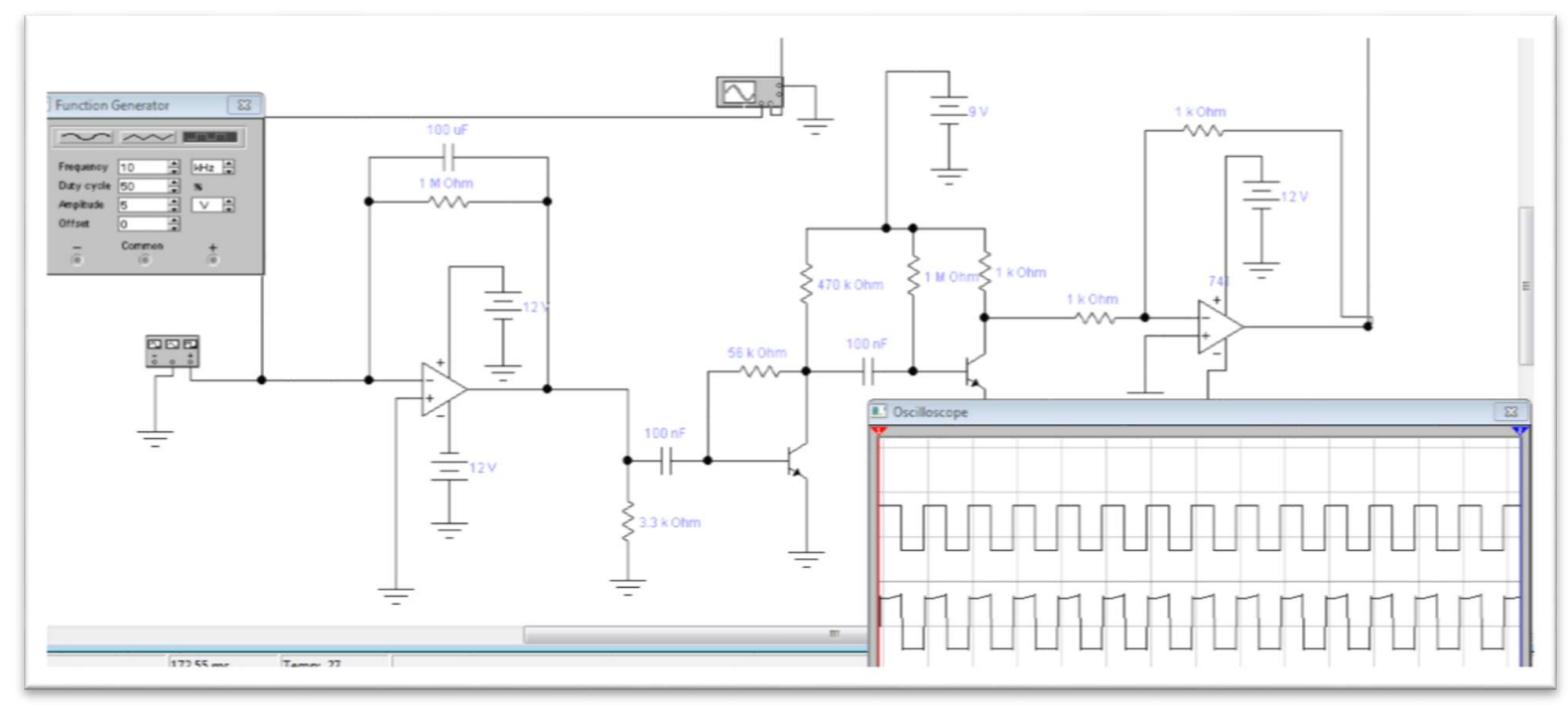

\section{Gambar 4. Simulasi sistem Visible Light Communication (VLC)}

Dengan menggunakan sinyal informasi yang berbeda, Gambar 4 menunjukan rangkaian VLC transmitter dan receiver yang telah disimulasikan. Pada gambar tersebut sinyal pulsa dimasukan ke dalam VLC transmitter dan kemudian diterima oleh VLC receiver dan didapatkan akhirnya terdapat keluaran sinyal yang sama dengan sinyal yang dikirimkan. Dalam simulasi tersebut, telah didapatkan bahwa rangkaian telah dirancang dan didapatkan hasil sesuai dengan yang diharapkan.

\subsection{Implementasi Sistem}

Secara umum, dalam mengimplementasikan rangkaian VLC transmitter dibutuhkan 2 buah blok, yaitu Rangkaian Signal Conditioner dan rangkaian LED. Gambar 5 menunjukan rangkaian VLC Transmitter yang telah diimplementasikan. Pada gambar tersebut terlihat bahwa VLC Transmitter yang terdiri atas: Signal Conditioner dan Light Emitting Diode (LED) telah diintegrasikan dalam sebuah sistem.

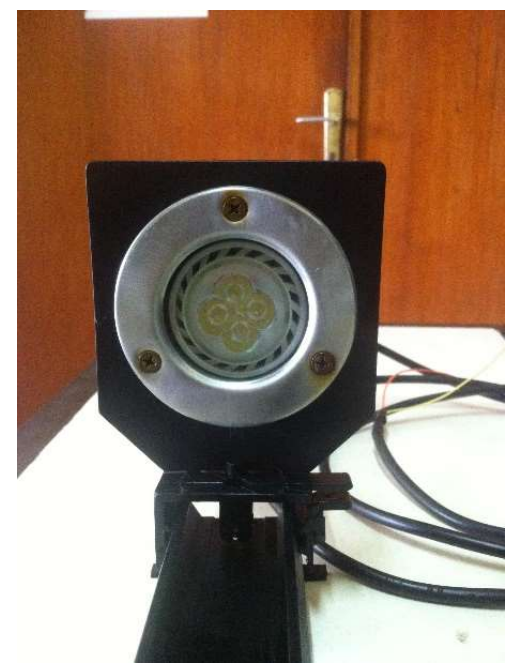

Gambar 5. VLC Transmitteryang telah diimplementasikan 
Sedangkan, rangkaian VLC Receiver terdiri atas rangkaian photosensor, dalam hal ini menggunakan photodioda, Rangkaian Penguat, dan Signal Conditioner, yang telah diimplementasikan ditunjukan pada Gambar 6. Pada gambar tersebut VLC Receiver yang terdiri atas: Photosensor, Amplifier, dan Signal Conditioner diintegrasikan dalam sebuah sistem.

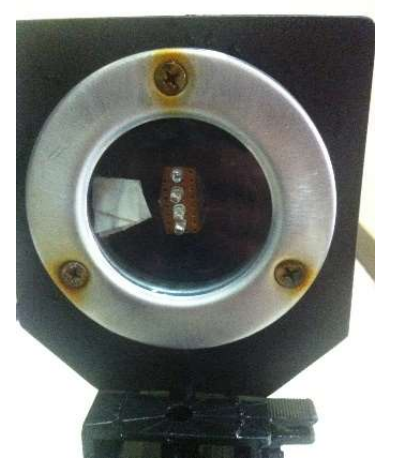

\section{Gambar 6. VLC Receiveryang telah diimplementasikan}

Sistem VLC transmitter dan receiver data yang telah diintegrasikan ditunjukan pada Gambar 7.
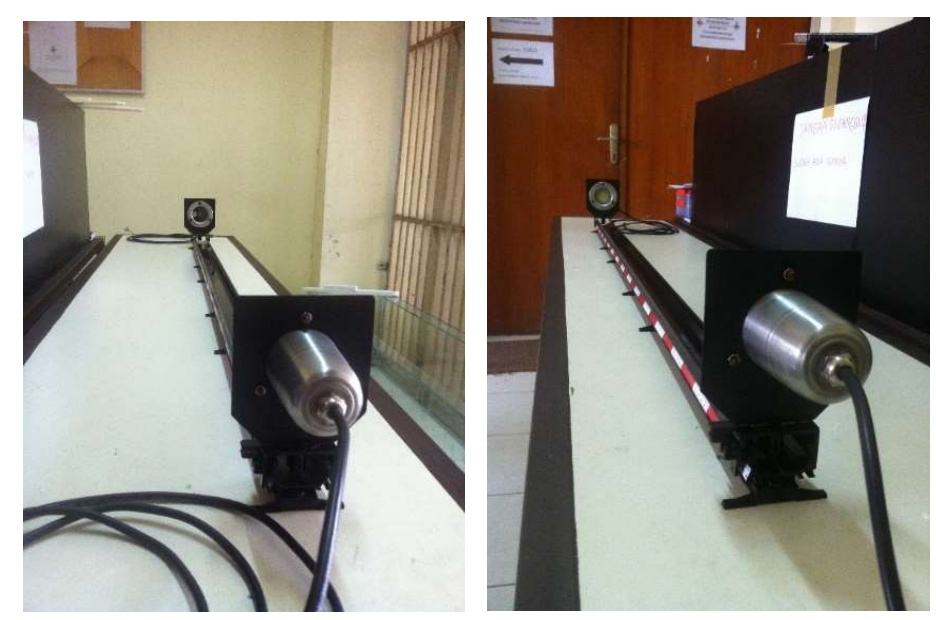

\section{Gambar 7. VLC Transceiver (Transmitter-Receiver)}

\section{HASIL DAN PEMBAHASAN}

Kinerja diukur dari hasil keluaran sistem yang meliputi beberapa pengujian yaitu :

\subsection{Pengujian Sistem dengan Jarak tetap dan frekuensi bervariasi}

Gambar 8 menunjukan blok pengujian pertama dari sistem yang telah dimplementasikan. Pada pengujian ini signal generator membangkitkan sinyal sinusoida dengan frekuensi $20 \mathrm{~Hz}$ sampai dengan $20.000 \mathrm{~Hz}$ yang merupakan frekuensi sinyal yang dapat didengarkan oleh manusia. 


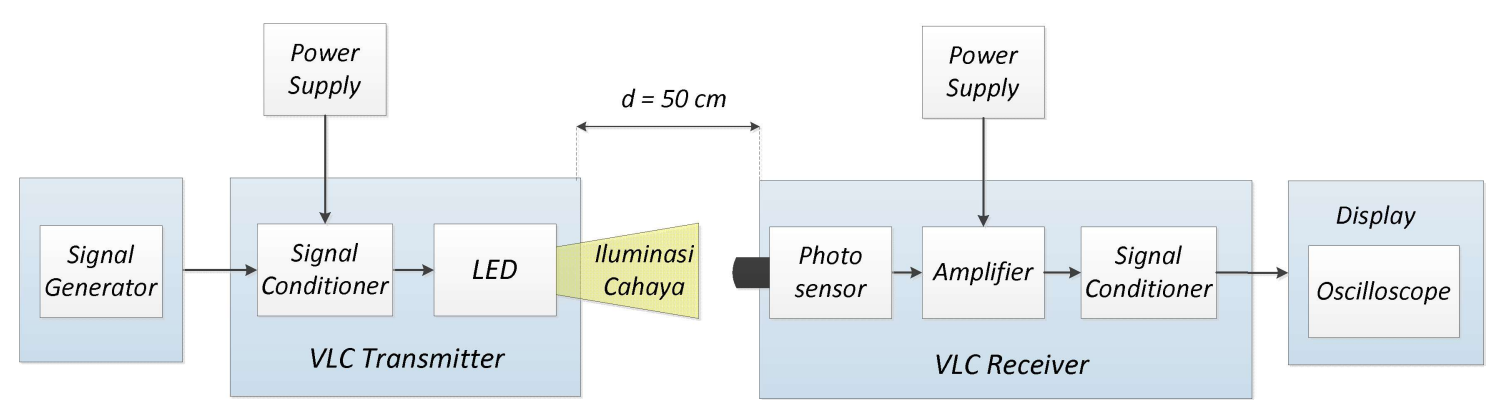

Gambar 8. Blok Diagram Pengujian sistem VLC dengan jarak 50 cm

Jarak antara transmitter dan receiver dibuat tetap yaitu $50 \mathrm{~cm}$. Keluaran dari sistem diukur oleh oscilloscope yang dibandingkan karakteristiknya dengan sinyal masukan kembali. Besaran Power Supply yang digunakan masing - masing 12 Volt pada transmitter dan receiver, dimana besaran ini digunakan untuk seluruh pengujian pada penelitian ini. Gambar 9 menunjukan sinyal masukan dan keluaran sistem yang terukur dengan oscilloscope.

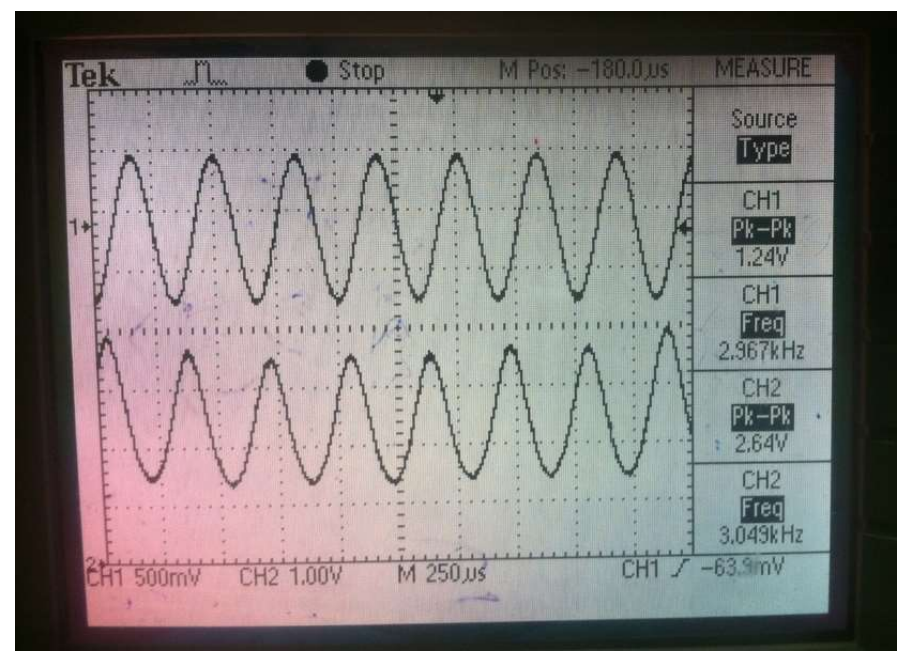

\section{Gambar 9. Sinyal Masukan (atas) dan Keluaran (bawah) sistem VLC}

Terlihat pada gambar tersebut sinyal keluaran sistem (bawah) mengalami pergeseran fasa sebesar 180 Derajat terhadap sinyal masukan (atas). Hal ini disebabkan oleh pengaruh dari kanal sistem transmisi yang digunakan. Pergeseran fasa tersebut dapat diatasi oleh rangkaian penggeser fasa (phase shifter) untuk mengembalikan sinyal keluaran ke bentuk yang seharusnya sama seperti sinyal masukan. Walaupun demikian, sistem yang dirancang dan diimplementasikan telah bekerja dengan baik yang dibuktikan dengan frekuensi yang dari sinyal masukan sama seperti frekuensi dari sinyal keluaran dari sistem. Tegangan dari sinyal keluaran pun telah mengalami penguatan sebesar 1,66 kalinya. Penguatan dari setiap sinyal berbeda - beda pada setiap pengukuran dan frekuensi dari sinyal yang dimasukan. Hal ini disebabkan oleh keadaan lingkungan dan kondisi pengukuran yang berubah setiap saat. Hasil pengujian yang dilakukan terhadap sistem dengan membuat sinyal masukan memiliki frekuensi yang berubah - ubah ditunjukan pada Gambar 10. 


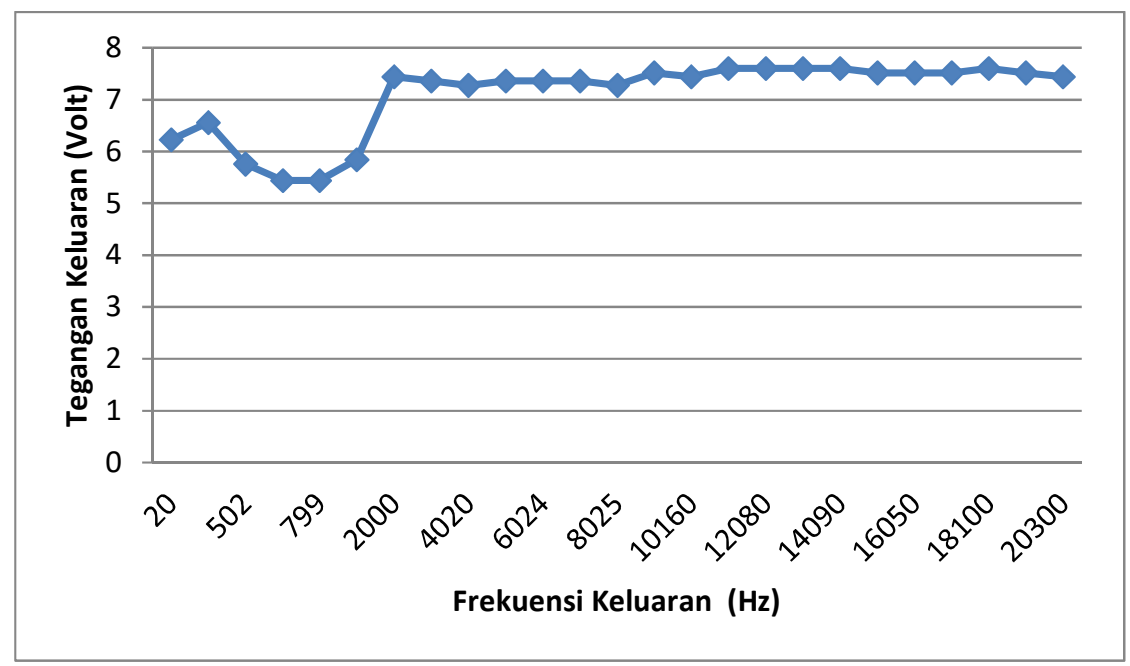

\section{Gambar 10. Grafik Perbandingan frekuensi sinyal keluaran dengan tegangan keluaran sistem dengan jarak tetap}

Pada pengujian ini signal generator membangkitkan sinyal sinusoida dengan tegangan 5 Volt dan frekuensi yang diubah dari $20 \mathrm{~Hz}$ sampai dengan $20.000 \mathrm{~Hz}$. Frekuensi tersebut adalah frekuensi sinyal yang dapat didengarkan oleh manusia. Sedangkan apabila untuk frekuensi percakapan (audio) memiliki besaran dari 300 sampai dengan $3400 \mathrm{~Hz}$, sehingga apabila pengujian yang pertama ini memiliki hasil yang baik maka dapat diartikan bahwa sinyal suara dalam bentuk percakapan (audio) memiliki kinerja yang baik pula. Dari hasil pengujian tersebut didapat bahwa sinyal dapat dilewatkan kepada sistem pada frekuensi $20 \mathrm{~Hz}$ sampai dengan $20000 \mathrm{~Hz}$ dengan rata - rata gain adalah 1,41 kali. Hal ini dapat diartikan sinyal informasi dengan frekuensi audio $(300-3400 \mathrm{~Hz})$ dapat dilewatkan menggunakan sistem ini pula.

\subsection{Pengujian Sistem dengan jarak (d) yang bervariasi dan frekuensi tetap.}

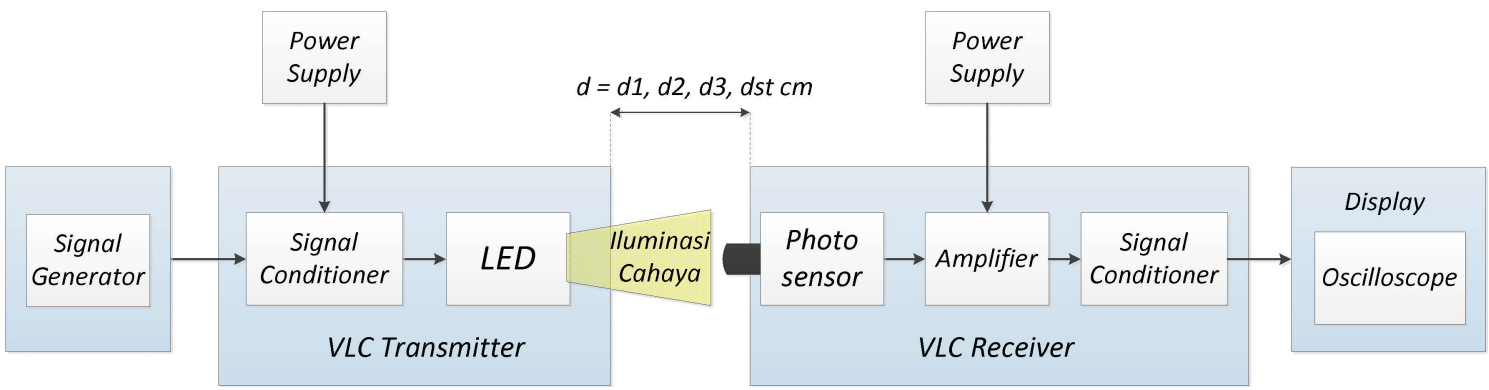

\section{Gambar 11. Blok Diagram Pengujian sistem VLC dengan jarak yang berubah ubah}

Gambar 11 menunjukan blok pengujian kedua dari sistem yang telah dimplementasikan. Pengujian ini hampir sama dengan pengujian pertama namun dengan jarak yang berubah ubah hingga sinyal tidak dapat diterima oleh Rx pada sistem yang telah di implementasikan. Pada pengujian ini digunakan frekuensi $3000 \mathrm{~Hz}$ sebagai frekuensi sinyal masukan. Hasil dari pengujian ini dapat dilihat pada Gambar 12. 


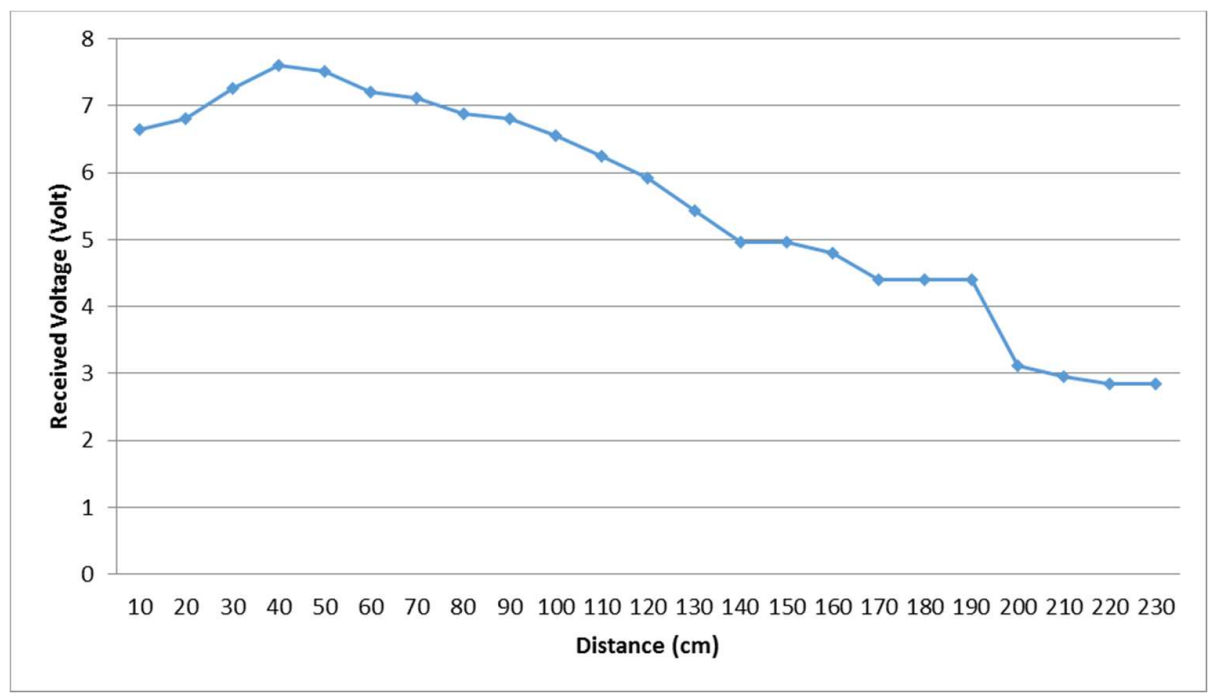

\section{Gambar 12. Grafik Perbandingan tegangan keluaran sistem berdasarkan jarak yang berubah - ubah}

Terlihat dari sinyal diatas semakin jauh jarak antara sumber cahaya atau LED dengan rangkaian penerima terjadi pengurangan tegangan hal ini membuktikan bahwa semakin jauh jarak maka semakin kecil sinyal yang mampu di terima oleh penerima,. Jarak maksimal yang telah dapat diuji oleh sistem adalah 2,3 m. Jarak tersebut dibatasi disebabkan oleh kebutuhan dalam melakukan percakapan antar dua orang sekitar kurang lebih 2 meter. Oleh karena itu pengujian hanya dilakukan pada jarak tersebut saja.

\subsection{Pengujian Sistem dengan menggunakan Color Filter berwarna merah}

Pada pengujian ketiga ini, transmitter dan receiver pada sistem akan digunakan sebuah filter warna (color filter) pada masing masing sisi, dimana pada bagian transmitter digunakan filter berwarna merah. Pengujian ini dilakukan untuk menganalisis pasangan warna yang cocok dengan menghasilkan kinerja pasangan warna yang paling baik. Blok diagram pengujian ditunjukan pada Gambar 13.

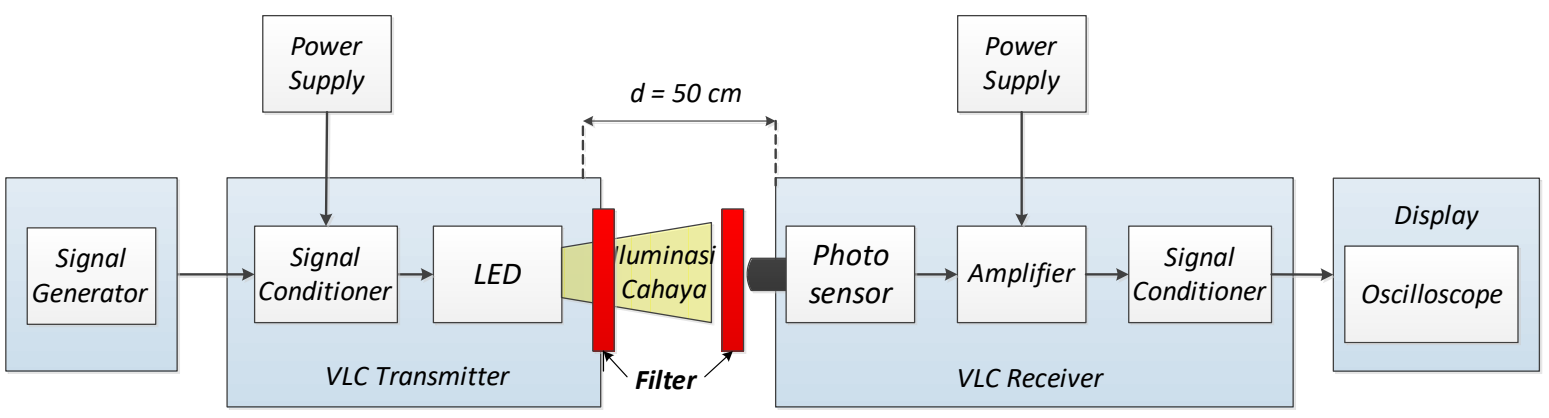

\section{Gambar 13. Blok Diagram Pengujian sistem VLC dengan color filter}

Sinyal informasi dibangkitkan dari signal generator dengan frekuensi audio $(300 \mathrm{~Hz}$ s/d $3400 \mathrm{~Hz}$ ) dengan tegangan 5 Volt. Pada pengujian ini digunakan filter warna merah pada transmitter dan beberapa warna pada receiver. Gambar 14 menunjukan 
beberapa filter warna yang digunakan, sedangkan Tabel 1 menunjukan posisi filter warna pada VLC Transmitter dan Receiver.

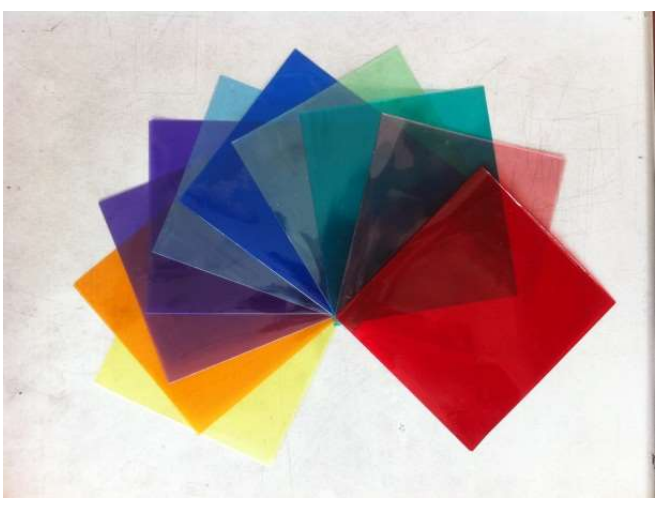

Gambar 14. Filter Warna (Color Filter)

Tabel 1. Pengujian sistem VLC dengan color filter(Red to Other Color)

\begin{tabular}{|l|l|}
\hline Filter pada Transmitter & \multicolumn{1}{c|}{ Filter pada Receiver } \\
\hline \multirow{5}{*}{ Red } & Red (Merah) \\
\cline { 2 - 2 } & Rose (Merah Muda) \\
\cline { 2 - 2 } & Green (Hijau) \\
\hline & Charteuse Green (Hijau Muda) \\
\cline { 2 - 2 } & Blue (Biru) \\
\hline & Azure (Biru Muda) \\
\cline { 2 - 2 } & Violet (Ungu) \\
\hline & Magenta (Ungu Muda) \\
\hline & Orange (Jingga) \\
\cline { 2 - 2 } & Yellow (Kuning) \\
\hline
\end{tabular}

Gambar 15 menunjukan hasil pengujian dari sistem dengan filter warna. Terlihat pada gambar tersebut bahwa tegangan sinyal yang dapat dilewatkan oleh sistem telah menghasilkan tegangan yang relatif baik diatas 1 Volt pada jarak $50 \mathrm{~cm}$ dengan frekuensi audio (300 - $3400 \mathrm{~Hz}$ ). Hal ini membuktikan bahwa sistem ini dapat digunakan sebagai transceiver (transmitter - receiver) Visible Light Communication (VLC). Disamping itu, pasangan filter warna merah di transmitter dan filter warna merah di receiver warna merah memiliki tegangan terima di receiver yang relatif lebih besar dibandingan menggunakan warna lain. 


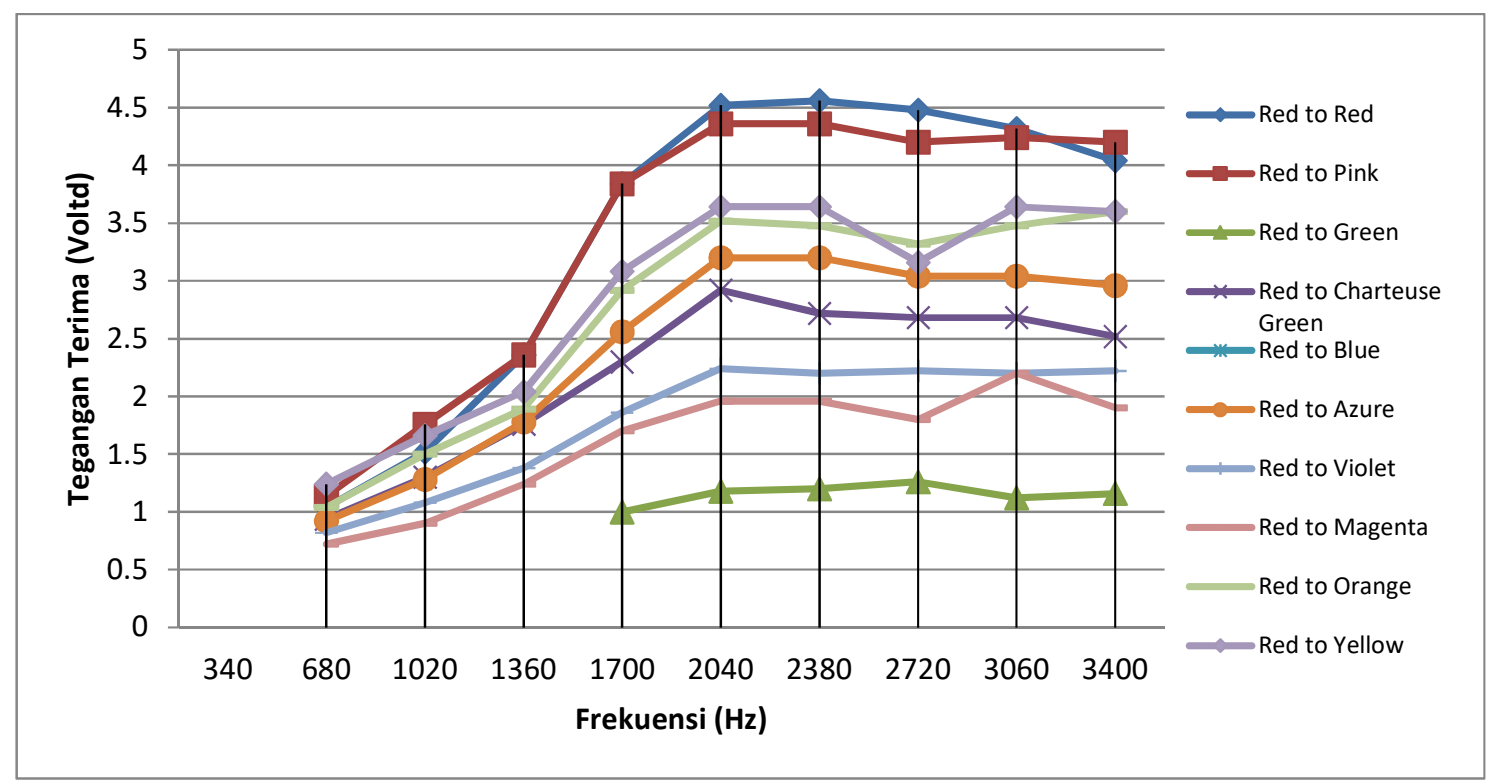

Gambar 15. Grafik tegangan keluaran sistem dengan filter merah pada transmitter

\subsection{Pengujian sistem menggunakan variasi pasangan Color Filter}

Pada tahapan ini, sistem akan diuji menggunakan variasi warna seperti yang ditunjukan pada Tabel 2. Hasil Pengujian ditunjukan pada Gambar 16.

Tabel 2. Pengujian sistem VLC dengan color filter

\begin{tabular}{|l|l|}
\hline \multicolumn{1}{|c|}{ Filter pada Transmitter } & \multicolumn{1}{c|}{ Filter pada Receiver } \\
\hline Rose (Merah Muda) & Red (Merah) \\
\hline Green (Hijau) & Rose (Merah Muda) \\
\hline Charteuse Green (Hijau Muda) & Green (Hijau) \\
\hline Blue (Biru) & Charteuse Green (Hijau Muda) \\
\hline Azure (Biru Muda) & Blue (Biru) \\
\hline Violet (Ungu) & Azure (Biru Muda) \\
\hline Magenta (Ungu Muda) & Violet (Ungu) \\
\hline Orange (Jingga) & Magenta (Ungu Muda) \\
\hline Yellow (Kuning) & Orange (Jingga) \\
\hline & Yellow (Kuning) \\
\hline
\end{tabular}




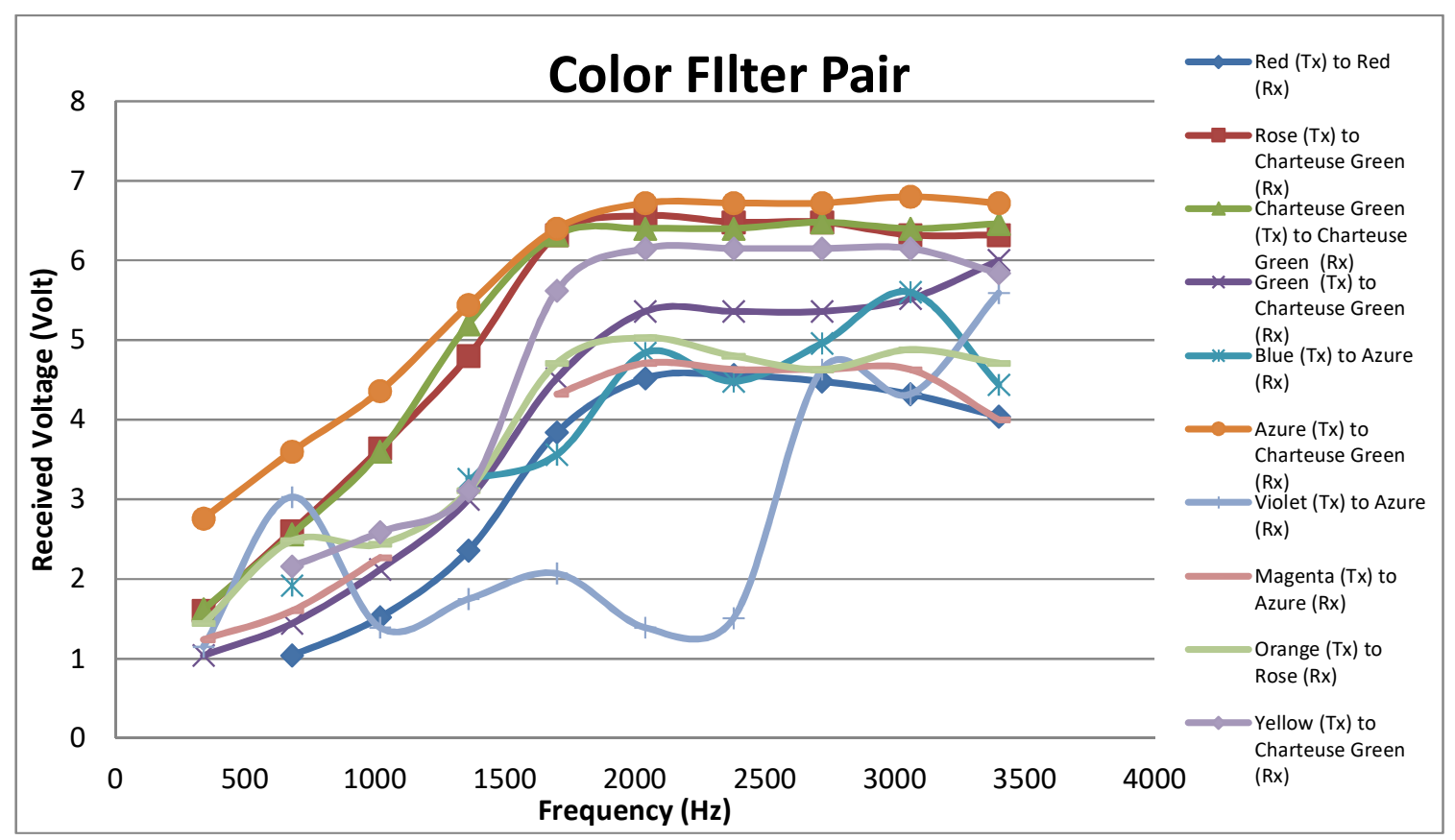

Gambar 16. Grafik tegangan keluaran sistem dengan beberapa variasi filter

Dengan pengujian yang sama, didapatkan beberapa hasil pengujian. Gambar 23 menunjukan kinerja dari sistem dengan menggunakan beberapa variasi warna filter pada transmitter dan receiver. Terlihat bahwa pasangan warna Azure yang digunakan di transmitter dan Charteuse Green di receiver memiliki kinerja yang paling baik dari penelitian ini. Hal ini dapat ditunjukan dengan tegangan terima pada receiver memiliki nilai yang paling tinggi dibandingkan pasangan warna yang lainnya. Dari gambar juga terlihat bahwa sinyal audio dengan frekuensi dari $300 \mathrm{~Hz}$ sampai dengan $3400 \mathrm{~Hz}$ dapat dilewatkan dengan baik oleh sistem. Dari hasil tersebut pasangan warna Azure dengan Charteuse Green, Charteuse Green dengan Charteuse Green, dan Rose dengan Charteuse Green dapat digunakan untuk sistem Bidirectional Visible Light Communication (Bi-VLC)

\section{KESIMPULAN}

Berdasarkan hasil penelitian dan pengukuran yang telah dilakukan terhadap sistem komunikasi menggunakan Visible Light ini, maka dapat diambil kesimpulan yaitu sebagai berikut:

1. Dari penelitian ini didapatkan jarak maksimal untuk pengiriman data dari transmitter ke receiver adalah 2,3 m hingga sinyal dapat diterima dengan baik.

2. Range frekuensi audio yaitu sebesar $300 \mathrm{~Hz}$ sampai dengan $3400 \mathrm{~Hz}$ telah dapat dilewatkan oleh sistem, sehingga sistem ini telah dapat digunakan untuk mengirimkan sinyal audio dari satu tempat ke tempat yang lain menggunakan VL.

3. Tiga buah pasangan warna, yaitu Azure dengan Charteuse Green, Charteuse Green dengan Charteuse Green, dan Rose dengan Charteuse Green dapat digunakan dalam sistem komunikasi karena memiliki kinerja yang paling baik. 


\section{UCAPAN TERIMA KASIH}

Penelitian ini didanai oleh Kementerian Riset, Teknologi dan Pendidikan Tinggi melalui Hibah Penelitian skema Penelitian Terapan Unggulan Perguruan Tinggi (PTUPT) pendanaan tahun 2018.

\section{DAFTAR RUJUKAN}

Bangun, Jape Athan, Lidyawati, Lita, Darlis, A. R. (2012). Perancangan dan Implementasi Sistem Komunikasi Laser Berdaya 1 mW. Reka Elkomika, 1(3), 223-232.

Bykhovsky, D., \& Arnon, S. (2014). Multiple Access Resource Allocation in Visible Light Communication Systems. Journal of Lightwave Technology, 32(8), 1594-1600.

Chang, C., Li, C., Lu, H., Member, S., Member, S., Lin, C., ... Cheng, C. (2014). A 100-Gb / s Multiple-Input Multiple-Output Visible Laser Light Communication System. Journal of Chemical Information and Modeling, 32(24), 4723-4729.

Cossu, G., Khalid, A. M., Choudhury, P., Corsini, R., \& Ciaramella, E. (2012). Long Distance Indoor High Speed Visible Light Communication System Based on RGB LEDs, 5-7.

Darlis, A. R., Cahyadi, W. A., \& Chung, Y.-H. (2018). Shore-to-Undersea Visible Light Communication. Wireless Personal Communications, 99(2), 681. https://doi.org/10.1007/s11277-017-5136-9

Hanzo, B. L., Haas, H., Rupp, M., \& Gyongyosi, L. (2012). Wireless Myths, Realities , and Futures: From 3G / 4G to Optical and Quantum Wireless. In Proceedings of the IEEE (pp. 1853-1888).

Khalid, A. M., Cossu, G., Corsini, R., Choudhury, P., Ciaramella, E., Khalid, A. M., ... Ciaramella, E. (2012). 1-Gb / s Transmission Over a Phosphorescent White LED by Using Rate-Adaptive Discrete Multitone Modulation White LED by Using Rate-Adaptive Discrete, 4(5), 0-9. https://doi.org/10.1109/JPHOT.2012.2210397

Khan, T. A., Tahir, M., \& Usman, A. (2012). Visible Light Communication using Wavelength Division Multiplexing for Smart Spaces, (January). https://doi.org/10.1109/CCNC.2012.6181092

Liao, C., Chang, Y., Ho, C., \& Wu, M. (2013). High-Speed GaN-Based Blue Light-Emitting Diodes With Gallium-Doped ZnO Current Spreading Layer, 34(5), 611-613.

Liu, Y. F., Yeh, C. H., \& Chow, C. W. (2013). Alternating-Signal-Biased System Design and Demonstration for Visible Light Communication Alternating-Signal-Biased System Design and Demonstration for Visible. IEEE Photonics Journal, 5(4). https://doi.org/10.1109/JPHOT.2013.2274762

Monteiro, E., \& Hranilovic, S. (2014). Design and Implementation of Color-Shift Keying for 
Visible Light Communications. Journal of Lightwave Technology, 32(10), 2053-2060. https://doi.org/10.1109/JLT.2014.2314358

Singh, R., O'Farrell, T., \& David, J. (2014). An Enhanced Colour Shift Keying Modulation Scheme for High Speed Wireless Visible Light Communications. Journal of Lightwave Technology, 8724, 1-1. https://doi.org/10.1109/JLT.2014.2328866

Wu, L., Zhang, Z., Dang, J., \& Liu, H. (2015). Adaptive Modulation Schemes For Visible Light Communications. Journal Of Lightwave Technology, 33(1), 117-125. 